\title{
The decision-making process of synthetic pesticide use in agricultural communities in Colombia: a grounded theory approach
}

\author{
El proceso de toma de decisiones para el uso de plaguicidas en comunidades \\ agricultoras en Colombia: una aproximación desde la teoría fundada
}

\author{
The decision-making process of synthetic pesticide use in agricultural \\ communities in Colombia: a grounded theory approach
}

\author{
Ysabel Polanco López de Mesa' \\ 1 PhD in Public Health. Universidad de Antioquia. E-mail: ysabel.polanco@udea.edu.co. orclD: https://orcid.org/0000-0003-2616-0160
}

Recibido: 16/02/2018. Aprobado: 03/12//2019. Publicado: 20/03/2020

López de Mesa, YP. The decision-making process of synthetic pesticide use in agricultural communities in Colombia: a grounded theory approach. Rev. Fac. Nac. Salud Pública. 2020; e331277. Dor: https://doi.org/10.17533/udea.rfnsp.e331277

\begin{abstract}
Objectives: to explore the decision-making process of agricultural workers associated with pesticide use and exposure; to deduce whether these processes differ between pesticide users and non-users; and to analyze the characteristics of these differences. Methodology: This study used a grounded theory approach to understand the decision-making process for pesticide use/non-use among agricultural workers in San Cristobal, Colombia. This study involved participant observation, individual interviews, and focus groups. Results: the theory developed to explain the decision-making process for pesticide use showed several categories including: the prospect of having a good harvest, efficient pest control, habituation to the use of pesticides, feeling obligated to use them, poor knowledge about pesticides, believing that pesticides increase the quality of the products, positive attitudes towards pesticide use, family support towards pesticide use, community pressure
\end{abstract}

and acceptance, economic fear, and market pressure. In the nonpesticide user group categories included: having better health, pesticides considered harmful for human health, pesticides being deleterious for the environment, habituation to working without pesticides, family and economic support, and negative attitude towards pesticide use. The decision-making process for personal protective equipment (PPE) use encompassed categories such as: feelings of powerlessness, economic difficulties, and belief that equipment is not necessary. Discussion: The decision-making process for pesticide use in agricultural communities is complex and varies between pesticide users and non-users. Conclusions: It is important to consider the intricate process of pesticide use in order to orient interventions in the agricultural sector.

-------Key words: perceptions, agriculture, pesticide exposure, grounded theory 


\section{Resumen}

Objetivo: explorar los aspectos relacionados con el proceso de toma de decisiones en agricultores asociado con el uso y la exposición a plaguicidas; y descubrir si estos procesos difieren entre usuarios y no usuarios de plaguicidas y las características de estas diferencias. Metodología: Este estudio utilizó la teoría fundada para entender el proceso de toma de decisiones de agricultores de San Cristóbal, Colombia, para usar o no usar plaguicidas. Esta investigación incluyó observación participativa, entrevistas individuales y grupos focales. Resultados: la teoría para explicar el proceso de toma de decisiones de usar plaguicidas incluyó categorías como: la idea de tener una buena cosecha, controlar las plagas eficientemente, hábito de usar plaguicidas, pobre conocimiento sobre plaguicidas, creer que los plaguicidas aumentan la calidad de los productos, entre otras. En el grupo de no usuarios de plaguicidas, algunas categorías fueron: tener mejor salud, los plaguicidas son considerados peligrosos para la salud humana y el medio ambiente, y estar acostumbrados a trabajar sin plaguicidas. El proceso de toma de decisiones para el uso de equipo de protección personal incluyo categorías como poco poder, dificultades económicas, y la creencia de que el equipo de protección no es necesario. Discusión: el proceso de toma de decisiones para usar o no plaguicidas en comunidades agricultoras es complejo y varía entre usuarios y no usuarios de plaguicidas. Conclusiones: es importante tener en cuenta la complejidad del proceso de toma de decisiones sobre el uso o no de plaguicidas con el fin de orientar apropiadamente las intervenciones en la población agricultora.

-Palabras clave: percepciones, agricultura, plaguicidas, exposición y teoría fundamentada.

\section{Resumen}

Objetivo: explorar os aspectos relacionados ao processo de tomada de decisão em agricultores associados ao uso e exposição a pesticidas; e descubra se esses processos diferem entre usuários e não usuários de pesticidas e as características dessas diferenças. Metodologia: Este estudo conhecia a teoria encontrada para entender o processo de tomada de decisão dos agricultores em San Cristóbal, Colômbia, para usar ou não usar pesticidas. Esta pesquisa incluiu observação participativa, entrevistas individuais e grupos focais. Resultados: A teoria para explicar o processo de tomada de decisão do uso de pesticidas inclui categorias como: a ideia de uma boa colheita, controle eficiente de pragas, hábito de uso de pesticidas, pouco conhecimento sobre pesticidas, acreditando que os pesticidas aumentam a qualidade dos pesticidas. os produtos, entre outros. No grupo de não usuários de pesticidas, algumas categorias foram: ter melhor saúde, pesticidas são perigosos para a saúde humana e para o meio ambiente e estar acostumados a trabalhar sem pesticidas. $\mathrm{O}$ processo de tomada de decisão para o uso de equipamentos de proteção individual inclui categorias como baixo consumo de energia, dificuldades financeiras e a crença de que o equipamento de proteção não é necessário. Discussão: O processo de tomada de decisão para usar ou não usar pesticidas em comunidades agrícolas é complexo e modifica entre usuários e não usuários de pesticidas. Conclusões: é importante levar em consideração a complexidade do processo de tomada de decisão sobre o uso ou não de agrotóxicos, a fim de orientar adequadamente as complicações na população agrícola.

---------Palavras-chave: percepções, agricultura, pesticidas, exposição e teoria fundamentada.

\section{Introduction}

Synthetic pesticides have been widely used in modern agricultural practices since their introduction in the 1950s [1]. Pesticides are associated with major and adverse health and environmental effects in different parts of the world $[2,3]$. The health effects of pesticides can be immediate, e.g., rashes, headaches, nausea, vomiting, shock, disorientation, respiratory failure, coma, and death [4]. Long-term health effects related to pesticide exposure, including cancer, and neurologic and reproductive problems, have also been documented in Colombia [5]. The severity and pervasiveness of the deleterious health effects associated with pesticide exposure make it a major global public health problem [6].
Agricultural production is one of the major economic sectors in Colombia. Use of pesticides is prevalent at both large and small-scale production facilities [7]. The agricultural population in Colombia is exposed to pesticides and is particularly vulnerable to concomitant health problems. This population is likely to experience occupational hazards $[4,8]$ and is marginalized with no minimal working safety conditions and educational opportunities [9]. Some local studies show that most agricultural workers have not received pesticide safety training and work without following pesticide safety measures [10].

A small number of studies have examined the decision-making process for pesticide use among agricultural communities from a qualitative perspective, specifically using a grounded theory approach [11]. Moreover this decision-making process has the potential 
to affect the health and safety of this agricultural population [12]. Most studies concur that the decisionmaking process that agricultural workers are faced with when deciding whether or not to use pesticides is intricate, not necessarily controlled by the degree of knowledge about the harmfulness of pesticides, and is deeply influenced by individual, interpersonal, sociocultural, economic, and political factors $[9,14]$. In many situations some pesticide users have less control over their decisions and less personal confidence to stop pesticide use than non-pesticide users [15].

Few studies in Colombia have explored the factors that influence and predict health-related behaviors associated with pesticide use and exposure $[12,16]$. It is of critical necessity to understand the unique work experiences and perceptions of agricultural workers in Colombia as a way to identify the full range of processes that influence pesticide use and exposure and affect their ability to protect themselves from workplace hazards $[5,15]$.

The following research question was defined for this study: what are the components and characteristics of the decision-making process for the use or non-use of pesticides for agriculture among the agricultural population in San Cristobal, Medellin, Colombia?

This study was guided by a grounded theory perspective with the aim of: 1) exploring the complexity of the decision-making process of agricultural workers associated with pesticide use and exposure; and 2) deducing whether these processes differ between pesticide users and non-users and, if they do, identifying the characteristics of the differences.

\section{Methods}

The research strategy was based on qualitative methods supported by a grounded theory approach, which used participant observation, interviews, and focus groups $(17,18)$. This qualitative method provides new perspectives to understand the problem of pesticide use in Colombia and the complex aspects of the decisionmaking process in relation to pesticide use. Grounded theory provides new understanding of the reasons implicated in the pesticide use process. It is important to note that all data produced by this study represents agricultural workers' views, perspectives and opinions.

Participants consisted of adult, male/female agricultural workers who lived in 10 of the 17 vereda rural divisions in San Cristobal. The community included in this study has practiced agriculture for generations and has used many varieties of pesticides. They mainly own their land and have certain decision-making freedoms in relation to their agricultural practices. This study used snowball sampling and purposive sampling techniques, allowing some participants to recommend other additional participants $[18,19]$. Two cognitive interviews were conducted with community members to test the instrument, to identify if some questions were confusing and whether questions were hard for participants to understand [20]. The information was collected through participant observation, 67 interviews, and 5 focus groups that were audio recorded. All the interviews and focus groups were conducted in Spanish. Subsequently, data were transcribed and analyzed using line by line coding, focused coding, axial coding and theoretical coding, thus creating themes, categories and dimensions using the N-Vivo8 ${ }^{\circledR}$ software. Constant comparative analysis was performed and the researcher checked for reliability and validity. This study obtained approval from the Institutional Review Board (IRB 02 ) at the University of Florida (protocol \# 2011-U0106) and from the Medical Ethical Committee at the University of Antioquia, Colombia (acta 015-2010). Informed consent was obtained from all participants.

\section{Participants}

All participants worked in agriculture. The majority were adult males $(54.43 \%)$. The average age was 53 years and $54 \%$ were pesticide users, and $46 \%$ were nonusers (practiced agroecology*).

\section{Data Analysis}

We used conventional thematic content analysis for data analysis $[19,21]$. Conventional thematic content analysis is frequently used when the goal is to uncover the key elements of respondents' statements [21]. Content analysis is a research method for the subjective interpretation of the content of text data through the systematic organizational process of coding and theme identification [22]. The following steps were followed: all transcripts were read thoroughly; codes were derived from the transcripts line by line; codes were named based on the words used by interviewees; after this focused coding was performed in order to use the most significant codes and themes, and axial coding was performed to relate categories to subcategories to reassemble the data that had fractured during the initial coding. Subsequently theoretical coding was performed

\footnotetext{
Agroecology refers to the application of ecological concepts and principles to the design and management of sustainable agroecosystems. Agroecology goes beyond the use of alternative practices to develop agroecosystems with minimal dependence on high agrochemical and energy inputs, and considers that ecological interactions provide the mechanisms for the systems to promote their own soil fertility, productivity and crop protection [27].
} 
in order to integrate the codes from the focused codes and themes $[24,25,26]$. These theoretical codes helped to provide coherence and to move the analytic story in a theoretical direction by finding different coding families. Ideas were unified analytically and keeping in mind the possible theoretical meanings of the data and codes. Additionally memos were used to raise focused codes to conceptual categories. The general context and particular conditions in which pesticide use occurs and changes depending on several influences were clarified. Some participants' strategies for dealing with family and social pressure in relation to pesticide use were also identified. Furthermore, theoretical sampling was performed by seeking pertinent data in order to develop the emerging theory. The theoretical sampling consisted in performing additional field observations, reading documents, participation in social meetings with some of the participants and re-interviewing additional people with a focus on the theoretical categories [23]. The categories were saturated with data and subsequently sorted to integrate the emerging theory. In this process more robust categories and penetrating analyses were created [19]. The development of the theory involved a process of revision and revelation [26].

\section{Results}

This section describes and analyzes the main theoretical categories in order to come up with the theory in relation to the decision-making process for pesticide use. Additionally, the topic of the use of protective equipment emerged as having important components. An explanatory theory emerged from the data in relation to the factors that influence the decision of whether or not to use this equipment.

Main theoretical categories in relation to the aspects associated with the decision-making process for pesticide use

The most important categories that the theory developed in relation to the decision-making process for pesticide varied between pesticide users and non-users. For pesticide users the content areas that emerged included: the prospect of having a good harvest, efficient pest control, habituation to use of pesticides, feeling obligated to do so, poor knowledge about pesticides, believing that pesticides increase the quality of the products, positive attitudes towards pesticide use, family support towards pesticide use, community pressure and acceptance, economic fear, and market pressure.

Community beliefs about pesticide effectiveness emerged and the desire to adhere to a high-speed production was clearly expressed: "life and consumption take place at high speeds" (Participant No. 23) and "The harvest has to be ready and good for sale as quickly as possible" (Participant No. 42). Most pesticide users in the community react negatively when someone in the area quits pesticide use or even when someone stops using pesticides: "Are you dumb, stupid, or crazy?"; "A small production is a good result? What a waste of time!",; "That does not work, you will starve!"; "We do not want to work with rotten water and manure" (Participant Nos. $35,45,60$, respectively). Non-pesticide users mentioned that it is very hard to raise community awareness.

Some participants expressed concerns about their partners (mostly wives) mainly being affected by pesticides when they breathe air contaminated with these substances after spraying. They can also be affected by washing (by hand) the clothes used by their partners during pesticide spraying/applications and by eating food that contains pesticides. Male agricultural workers believed women are more susceptible or "delicate" than men and are more easily affected to the point of "suffering miscarriage and skin allergies" (Participant No 45).

Several agricultural workers indicated that there is no harm to them: "If I cover myself with a cotton mask nothing happens" (Participant No. 62); or "If I wash the vegetables with hot water and bleach before we consume them, pesticides will not affect us" (Participant No. 52). A consistently negative perception of pesticides' effects on children's health existed because adult agricultural workers (male and female alike) judged that children have "weaker bodies than adults" (Participant No. 34). They believed pesticides can produce negative effects, even starting at conception, such as cleft palate or other malformations: "pesticides can affect the fetus in general" (Participant No. 41). "Pesticides can produce other problems such as intoxications, respiratory problems, allergies, skin irritations, and respiratory diseases in children" (Participant No. 30). Concerning the possibility of stopping pesticide use, individuals in the pesticide user group held a negative attitude; they would stop if they could have economic guarantees, e.g., clear state or private initiatives to help them financially and logistically in the event of losing their crops and harvest. Few pesticide users displayed a positive attitude toward the possibility of quitting pesticide use if they received good technical advice.

For non-pesticide users the main domains in the decision-making process for not using pesticides included: the fact that not using pesticides makes them have better health standards, the consideration that pesticides are harmful for human health and for the environment, they enjoy working without pesticides, they feel family support against pesticide use, they experience economic support, and they possess a negative attitude towards pesticide use. In terms of family support, partners in general approved agroecological practices: 
"she feels happy because with agroecology productivity is not great but there is health and lots of other good things that come with it" (Participant No. 24) or "when I changed to agroecology, I did it mainly because I had support from my family." (Participant No. 36).

Non-pesticide users expressed the attitude of being "firm" in their decision and mentioned a feeling of satisfaction and pride about going "clean" that made them steadfast against going back to pesticide use mainly because "we think pesticides are harmful for our health and the environment, I would never use pesticides again" (Participant No. 62). Non-pesticide users expressed that after having learned to grow their crops without pesticides, they would not start pesticide use again: "it would be like stepping back and losing what I have learned" (Participant No. 66).

Theoretical categories associated with use of protective equipment

The theoretical categories that explained the inadequate use of personal protective equipment (PPE) included: feelings of powerlessness against bosses, economic difficulties because of the cost of the equipment, belief that the equipment is not necessary, belief of physical strength, insufficient training about safety practices, and habituation to spraying without PPE, poorly enforced policies that regulate the use of PPE.

The most commonly used equipment included plastic boots (98.5\%), cotton mask (9\%), and plastic goggles (9\%). During the participant observations, agricultural workers never used appropriate PPE throughout pesticides preparation or application. Participants reported that they have rarely received visits from regulatory agencies for PPE training or supervision.

Most pesticide users in this study had not received any training at all. In the better cases, they read the label on the container and followed directions as they interpret them: "I have not received any training but the pesticide containers says: use mask, gloves and shower after use, sometimes I take a shower right after spraying and other times at night because I am very busy." (Participant No. 26).

Economic constraints negatively impact the adoption of adequate protection schemes against pesticides, as a complete set of PPE can be expensive and virtually impossible to purchase and maintain by an already subdued family economy.

\section{Discussion}

Lack of thorough understanding of the harmfulness of pesticides brings up an important issue because it shows how pesticide use is a human behavior related to factors like habit, social norms, or cultural acceptance without clear justification for this behavior. These complex explanations of social and individual aspects of the decision-making process provide additional elements to analyze the problem of pesticide use in Colombia and as public health practitioners, and researchers, it is urgent to take these processes into account to work with more socially appropriate perspectives. Additionally it is important to increase the level of awareness about the adverse effects of pesticide use because workers might know pesticides are dangerous but they just "do not think about the consequences."[15].

Many workers avoid attempting to stop pesticide use due to the economic fear they experience concerning a decrease in income linked to crop failure and/or reduced possibilities to market their products when shifting from agrochemical-based agriculture to agroecology. Well-established sources of financial support to their work could improve economic stability, thus facilitating the adoption of agroecological practices [27]. Considering that the market exerts a profound influence on deciding whether or not to use pesticides, more support to agricultural workers in the realm of fair trade and agroecological markets is urgently needed. This economic support could be accomplished through new governmental policies that foster agroecological practices so as to assure logistic and financial support to agricultural workers [27].

Many pesticide-related ideas were culturally accepted. Pesticides were considered as something normal, and a desirable and helpful tool in agriculture. Culturally sensitive educational interventions about the harms of pesticides to human health and the environment would contribute to the transformation of this social norm.

Additional research efforts are also required to provide information about all these multi-level factors in other geographic areas of Colombia where intensive pesticide use is also prevalent. In Colombia variable cultural trends exist among agricultural communities, therefore qualitative studies in different regions could provide a better understanding of the myriad of factors associated with the decision-making process for pesticide use $[19,23]$. These findings could help researchers to design future culturally appropriate public health interventions.

Public health interventions would be beneficial in the pesticide user population in order to generate more awareness about the implications of pesticide use [2,28]. These activities could promote the development of a better-supported understanding of the negative impacts on health linked to the use of pesticides as well as the possibilities inherent to agroecological practices, with the aim of reducing or ideally eliminating pesticide use [27]. 
The main attitude towards continuing pesticide use among pesticide users was fear. The forms and causes of these fears and apprehensions should be studied in more detail in the near future with the aim of helping agricultural workers find alternatives to cope with it, based on a more integral understating of their problematic situation, and hence facilitate pesticide reduction. Nonpesticide users who have already overcome this fear could serve as partners and examples for guiding their fellow workers through the decision-making process.

Future public health interventions should try to increase knowledge about the harmfulness of pesticides, and to modify the beliefs reinforcing the idea that pesticides are necessary for crops. These interventions should also attempt to transform the negative attitudes towards stopping pesticide use so agricultural workers can be more confident about reducing their use and gradually transitioning to agroecological practices.

Most agricultural workers who have shifted to agroecological practices strongly emphasized that family support was crucial in making the decision. Based on this finding, prospective public health interventions focused on strengthening family support should contribute to facilitating the decision-making process for reducing/ stopping pesticide use. Thus, upcoming studies should explore family dynamics and social networks in more detail, as well as their role in the decision-making process for pesticide use or non- use.

Future interventions should also include the community in order to transform social norms about cultural acceptance of pesticides in the community. At the political level, policy makers should work with the advice of academia and community members, to design coherent laws and regulations for pesticide use and be more vigilant about their enforcement.

The frequency of having received PPE and pesticide preparation training in this study population was low. Some research shows that appropriate training reduces the health risks in agricultural practices $[2,14]$. Therefore, there is a clear need to improve safety conditions and training in this population in Colombia in order to reduce occupational hazards. Public health interventions targeted towards this population should incorporate activities aimed to increase awareness about the importance of the use of PPE followed by a subsequent goal of producing behavioral change that can improve the use of these protective devices.

Finally, it is relevant to analyze the situation of pesticide use not only in relation to human health impacts, but also to the contamination of superficial and ground water sources, and soil degradation[29]. Moreover, pesticides contaminate many agricultural products by altering their nutritional properties and also leaving pesticide residues. Thus human beings are unquestionably exposed to these products, impacting their health [30, 31]. Pesticide users in San Cristobal are also contributing to this contamination and it is urgent to develop different interventions to improve this situation.

\section{Conclusions}

It is important to take into account the intricate process of pesticide use in order to properly orient interventions in the agricultural and health sector. Moreover, future research and public health and environmental policies on these topics are urgently needed in order to diminish the exposure of and risks to the agricultural population, including children who generally do not apply pesticides directly but are exposed to them by other means. Therefore, their health is highly affected in the short and long term. Additionally, it is important to take into account the environmental contamination of the soil, water and air, considering that as human beings we are part of a coordinated and balanced natural system and if we alter it, we also experience the impact of these changes.

\section{Acknowledgements:}

I would like to thank Barbara Curbow (University of Maryland) and Amy Ellen Young (University of Florida) for all their academic advice and support in this project. Thanks to the Compton Foundation for Tropical Research and Development at the University of Florida, for the economic support in this project. I also thank the agricultural workers who participated in this study for their time and valuable testimonies.

\section{Conflict of interest}

There is no conflict of interest in this study.

\section{References}

1. Carson R. Silent spring. Anniversar. Houghton Mifflin Company; 2002. $400 \mathrm{p}$.

2. Suk WA, Ahanchian H, Asante KA, Carpenter DO, Diaz-Barriga F, Ha EH, et al. Environmental pollution: An underrecognized threat to children's health, especially in low- and middle-income countries. Environ Health Perspect. 2016;124(3):A43-5.

3. Yadav IC, Devi NL, Syed JH, Cheng Z, Li J, Zhang G, et al. Current status of persistent organic pesticides residues in air, water, and soil, and their possible effect on neighboring countries: A comprehensive review of India. Sci Total Environ [Internet]. 2015;511:123-37. Available from: http://dx.doi.org/10.1016/j. scitotenv.2014.12.041

4. Kim KH, Kabir E, Jahan SA. Exposure to pesticides and the associated human health effects. Sci Total Environ [Internet]. 2017;575:525-35. Available from: http://dx.doi.org/10.1016/j. scitotenv.2016.09.009 
5. Nivia E. Las mujeres y los plaguicidas [Internet]. Rionegro, Antioquia, Colombia; 2010. Available from: http://rapaluruguay. org/publicaciones/e_n_2010.pdf

6. Blair A, Ritz B, Wesseling C, Freeman L. Pesticides and human health. Occup Env Med. 2014;0(0):1-3.

7. Pimentel D. Sustaining agriculture and the rural environment. Ecol Econ. 2007;63(2-3):635-6.

8. Kainga PE, Miller TA, Epidi TT. Assessment of Awareness of Benefits and Hazards Posed by Agricultural Pesticides to Farmers in Selected Communities of Bayelsa State, Nigeria. Int J Res Agric For. 2016;3(2):32-40.

9. Martinez-Alier J, Anguelovski I, Bond P, Bene D Del, Demaria F, Gerber J-F, et al. Between activism and science: grassroots concepts for sustainability coined by Environmental Justice Organizations. J Polit Ecol [Internet]. 2014;21(1):19. Available from: https://journals.uair.arizona.edu/index.php/JPE/article/ view/21124

10. Tabares J, López Y. Salud y riesgos ocupacionales por el manejo de plaguicidas en campesinos agricultores, municipio de Marinilla, Antioquia, 2009. Rev Fac Nac Salud Pública. 2011;29(4):432-44.

11. Daouda O, Bryant C. Analysis of Power Relations among Actors and Institutions in the Process of Agricultural Adaptation to Climate Change and Variability from the Diffusion of Innovations Perspective. Agric Adapt to Clim Chang. 2016;27-51.

12. Sanmiguel-Valderrama $O$. The feminization and racialization labor in the Colombian fresh-cut flower industry. J Dev Soc. 2007;23:71-88.

13. Salazar M, Napolitano M, Scherer J, McCauley L. Hispanic Adolescent Farmworkers' Perceptions Associated With Pesticide Exposure. West J Nurs Res. 2004;26:146-66.

14. Damalas C, Koutroubas S. Farmers' Training on Pesticide Use Is Associated with Elevated Safety Behavior. Toxics [Internet] 2017;5(3):19. Available from: http://www.mdpi.com/2305$6304 / 5 / 3 / 19$

15. Polanco Y, Salazar J, Curbow B. A quantitative analysis of Colombian campesinos' use of pesticides: perceived control and confidence in this use. Rev Fac Nac Salud Pública. 2014;32(3):373-82.

16. Loaiza A. Lineamientos de política sobre el uso y manejo mesurado de plaguicidas en el sector agropecuario del departamento de Antioquia. Convenio interinstitucional, 23 dic., 2003, entre: CEIBA, CORNARE y DAMA-ANTIOQUIA. Medellín, CO. s.n.t [Internet]. Medellin: Gobernacion de Antioquia; 2005. p. 140. Available from: http://unicesar.ambientalex.info/infoCT/ Lineamientossobreplaguicidas.pdf

17. Bryman A. Social Research Methods [Internet]. 2015. 1-80 p. Available from: https://socialresearchmethods.net/kb/qualval.php

18. Flick U. An introduction to qualitative research. Sage [Internet] 2009;4th:529. Available from: http://books.google.cz/ books?id=sFv1oWX2DoEC
19. O’Reilly K, Paper D, Marx S, Watling CJ, Lingard L, Matavire R, et al. Grounded Theory as a General Research Methodology. Organ Res Methods [Internet]. 2015;18(4):305-23. Available from: http://orm.sagepub.com/cgi/doi/10.1177/1094428115574858\%5 Cnhttp://www.sagepub.com/books/Book227372?siteId=sage-us \&prodTypes $=$ Books\&q $=$ Handbook + of + Qualitative + Research + in +Psychology\&fs=1\%5Cnhttp://qhr.sagepub.com/cgi/doi/10.1177 /1049732305285972\%5Cnhttp://search.ebsc

20. Sooniste T, Granhag P, Stromwall L, Vrij A. Statements about true and false intentions: Using the Cognitive Interview to magnify the differences. Scand J Psychol. 2015;56:371-8.

21. Green, J, and Thorogood N. Qualitative Methods for Health Research, Sage Publications.No Title. Third edit. Seaman J, editor. London: SAGE Publications; 2014. 339 p.

22. Hsieh H., Shannon SE. Three approaches to qualitative content analysis. Qual Health Res. 2005;15:1277-88.

23. Charmaz K. Constructing grounded theory, a practical guide through qualitative analysis. first edit. London: SAGE publications; 2008.

24. Bernard H. Research Methods in Anthropology: Qualitative and Quantitative Approaches. Fourth edi. AltaMira Press; 2006.

25. Richards L, Morse J. Read me First for a User's Guide to Qualitative Methods. Second edi. SAGE Publications; 2007.

26. Morse J. Asuntos criticos en los metodos de investigacion cualitativa. primera ed. Medellin: Universidad de Antioquia; 2003.

27. Altiery M. Agroecology The Science Of Sustainable Agriculture. Second edi. CRC Press; 2018. 448 p.

28. Harrison J. Pesticide Drift and the Pursue of Environmental Justice. London: Massachusetts Institute of Technology Press; 2011. $270 \mathrm{p}$.

29. Arias-Esteves M, Lopez-Periago E, Martinez-Carballo E, SimalGandara J, Mejuto J, Garcia-Rio L. The mobility and degradation of pesticides in soils and the pollution of groundwater resources. Agric, Ecosyst. Environ, 2008, 123, 247-260". doi:10.1016/j. agee.2007.07.011.

30. González-Rodríguez R. M, Rial-Otero R , Cancho-Grande B, Gonzalez-Barreiro C, Simal-Gándara J. A review on the fate of pesticides during the processes within the food production chain. Critical Reviews in Food Science and Nutrition, 2011, 51(2), 99114. Availablefrom: https://www.tandfonline.com/doi/full/10.108 0/10408390903432625?scroll=top\&needAccess $=$ true

31. Regueiro J, Lopez-Fernandez O, Rial-Otero R, Cancho-Grande B, Simal-Gandara J. A Review on the Fermentation of Foods and the Residues of Pesticides-Biotransformation of Pesticides and Effects on Fermentation and Food Quality. Critical Reviews in Food Science and Nutrition, 2015, 55(6), 839-863. Available from: https://www.tandfonline.com/doi/abs/10.1080/10408398.2 012.677872 